\title{
The Effect of Misalignment of CEO Personality and Corporate Governance Structures on Firm Performance
}

\author{
Irene M. Gordon, Karel Hrazdil * D, Johnny Jermias and Xin Li \\ Beedie School of Business, Simon Fraser University, Vancouver, BC V5A 1S6, Canada; \\ irene_gordon@sfu.ca (I.M.G.); johnny_jermias@sfu.ca (J.J.); xin_li_12@sfu.ca (X.L.) \\ * Correspondence: karel_hrazdil@sfu.ca
}

\section{check for}

updates

Citation: Gordon, Irene M., Karel Hrazdil, Johnny Jermias, and Xin Li. 2021. The Effect of Misalignment of CEO Personality and Corporate Governance Structures on Firm Performance. Journal of Risk and Financial Management 14: 375. https://doi.org/10.3390/ jrfm14080375

Academic Editor: Alireza

Tourani Rad

Received: 28 July 2021

Accepted: 12 August 2021

Published: 15 August 2021

Publisher's Note: MDPI stays neutral with regard to jurisdictional claims in published maps and institutional affiliations.

Copyright: (c) 2021 by the authors. Licensee MDPI, Basel, Switzerland. This article is an open access article distributed under the terms and conditions of the Creative Commons Attribution (CC BY) license (https:/ creativecommons.org/licenses/by/ $4.0 /)$.

\begin{abstract}
We utilize the IBM Watson Personality Insights service to analyze CEOs' verbal communication during conference calls to infer CEOs' Big Five personality traits, which we employ to estimate their risk tolerance levels. We then explore whether the misalignment of CEO risk tolerance and governance structures is associated with company performance. Using a two-stage contingency approach, we test two hypotheses: (1) CEO risk tolerance and corporate governance structures are associated; and (2) misalignment of these structures with risk tolerance is negatively associated with financial performance. Based on a sample of 8208 firm-year observations during 2002-2013, we find support for both predictions. Our results support upper echelons theory and suggest that knowledge about CEOs' inherent personality traits is important and relevant for governance mechanisms to work effectively.
\end{abstract}

Keywords: CEO personality; Big Five; corporate governance; performance

\section{Introduction}

Corporate governance structures, used for direction and control purposes, have been the subject of discussion by practitioners, academics, and regulators. Some consensus has emerged regarding effective governance mechanisms in improving firm performance (Adrian and Wright 2020; Seijts et al. 2019) with various guidelines implemented to enhance corporate governance and management practices (OECD 2015). However, survey studies suggest that, at best, the evidence is mixed concerning the hypothesis that better corporate governance results in improved firm performance (Tingle 2017). The existing literature offers a range of plausible explanations that may partially explain the mixed results, including the variance in board composition among firms, unknown determinants of governance structures, the influence of multiple factors taken together, the 2002 Sarbanes-Oxley (SOX) Act, board independence, and the lack of frequent board meetings. Some researchers (e.g., Hutchinson and Gul 2004; Simerly and Li 2000; Gani and Jermias 2006) argue that the conflicting evidence reported by prior studies may be due in part to the approaches used. Most prior studies in this area use a universal approach by investigating the direct effect of corporate governance on performance. Hutchinson and Gul (2004), for example, provide evidence that good corporate governance indirectly affects the relationship between a firm's growth opportunity and its performance. These authors call for future research to investigate the joint effects of corporate governance and their contextual variables on firms performance. Addressing the role of contextual variables could provide an opportunity to expand our understanding of the relationship between corporate governance and firm performance. Our study explores this challenge by employing a contingency approach to investigate the effect of misalignment between CEO risk tolerance and corporate governance structures on firm performance.

To better understand the link between corporate governance and performance, we test upper echelons theory and examine whether and how the misalignment of CEO risk 
tolerance $^{1}$ (based on a combination of the Big Five personality traits: openness, conscientiousness, extraversion, agreeableness, and neuroticism (OCEAN)) and governance structures $^{2}$ is associated with firm performance. Our investigation of the effect of CEO risk tolerance and governance structure misalignment on performance relies on a contingency approach (Bruns and Waterhouse 1975; Waterhouse and Tiessen 1978). The premise behind a contingency approach is that no one governance structure applies equally well to all organizations in all circumstances. To be effective, a particular form of governance structure needs to be properly aligned ${ }^{3}$ with the leadership style of the top executives (Schein 1983). Researchers (e.g., Gerdin and Greve 2004; Milgrom and Roberts 1992; Schein 1983) argue that companies dynamically learn throughout their life cycle and adjust their governance structure to match their leadership style to achieve the optimal configuration. Following Ittner and Larcker (2001), we measure risk tolerance-governance structure misalignment based on the degree to which the observed configurations deviate from the 'optimal' configurations for a given risk tolerance level, as indicated by the residual of each observation. This approach has been used effectively by previous researchers (e.g., Gani and Jermias 2012; King et al. 2010). To estimate the risk tolerance of U.S. CEOs, we use IBM Watson Personality Insights (hereafter IBM Watson) linguistic analytics software to analyze the verbal communication content of CEOs during conference calls to objectively infer their personality characteristics along five primary personality dimensions (OCEAN). Given that any individual is the sum of his/her personality traits, we construct a composite index of the five traits (labeled as risk tolerance by Hrazdil et al. (2020)) to gauge the misalignment of CEO risk tolerance to governance structures. These results become the input to a second stage that examines how the misalignment of CEO risk tolerance and governance structures is associated with firm financial performance. To the best of our knowledge, this is the first study to use personal characteristics to provide insights into how this misalignment helps explain firm performance.

We find that CEO risk tolerance is positively related to board independence and board members' nationality mix, that CEO duality is negatively related to CEO risk tolerance, and that the misalignment between CEO risk tolerance and corporate governance structures negatively affects firm performance.

Our results make several contributions to the literature. First, we establish that our proxy for inherent risk tolerance (based on the Big Five personality traits) is associated with risk-taking actions by CEOs. Specifically, we follow Cain and McKeon (2016), who find evidence that CEOs who possess private pilot licenses are associated with riskier firms, and show that CEO pilots are significantly more risk tolerant than non-pilots. Second, we provide support for upper echelons theory in a corporate governance setting, where, for the first time, we show that more risk tolerant CEOs (based on their Big Five personality traits) are overseen by boards where the chairman is separate from the CEO and where the board is comprised of more independent directors, and who are more ethnically diverse. These results provide evidence that board diversity and board member independence are effective corporate governance structures and support the argument that board member diversity and independent board members represent "best practice" in ensuring that upper echelon executives protect shareholder interest. Third, we apply a contingency approach, which allows us to extend the literature that has explored the relationship between corporate governance and performance but has excluded the effect of CEO risk tolerance. We depart from the traditional one-dimensional analysis of corporate governance and performance and show that the misalignment between personality and governance structure is detrimental to a firm's financial performance, measured by return on common equity and Tobin's Q. Overall, our results suggest that knowledge about CEOs' inherent personality traits is important and relevant for governance mechanisms to work effectively (Seijts et al. 2019). 
The remainder of our paper is organized into four sections. Section 2 situates our research within the literature, providing context and leading to our hypotheses. Section 3 provides methodological details. Section 4 outlines our results and findings. Section 5 provides a discussion and puts forward conclusions, including limitations of the study and suggestions for future research.

\section{Literature and Hypotheses}

Financial economics theory considers risk aversion to be a key determinant of individuals' economic behavior, assuming that risk-tolerant executives influence a wide variety of economic outcomes ranging from principal-agent contracting to asset pricing (Epstein 1998; Jensen and Murphy 1990; Page 2018). However, empirical evidence supporting these theoretical predictions is scarce, not least because it is difficult to objectively measure inherent risk tolerance at the individual executive level. To provide context to our study of the misalignment of CEO risk tolerance and governance structure on performance, we summarize pertinent literature on CEO personality characteristics, corporate governance, and firm performance.

\subsection{CEO Personality Characteristics}

In their pioneering work, Hambrick and Mason (1984, p. 193) define organizational outcomes as "reflections of the values and cognitive bases of powerful actors". These powerful actors are the 'upper echelons' (executives) who wield influence over their organizations' strategic choices and effectiveness. In other words, organizations are viewed as reflections of both top executives' unique backgrounds and personalities (Finkelstein et al. 2009). Based on the idea that corporate strategic choices and decision outcomes can be predicted by individual managerial characteristics and idiosyncrasies, the upper echelons perspective proposes that experiences, values, and personalities of CEOs shape their interpretation of the environment, which in turn influences strategic choices and organizational effectiveness (Hambrick 2007).

Personality psychology studies personality and its variation among individuals (Judge et al. 2002) and has been employed in the accounting and management literature. Plöckinger et al. (2016) review sixty studies that analyze the effect of upper echelons and/or executive characteristics on financial accounting choices. Their results suggest that top management executives, overseen by a board, exert significant influence on financial reporting decisions, supporting upper echelons theory predictions. Recent studies relate executives' behavioral traits to corporate financial policies approved by the board such as capital structure (Hackbarth 2008), financing (Malmendier et al. 2011), compensation packages (Graham et al. 2013), investment management style (Mayfield et al. 2008), and long-term firm survival (Ciavarella et al. 2004).

The management literature further investigates which personality traits make CEOs more effective leaders. For example, Zhu and Chen (2015) find that narcissistic CEOs exhibit strengths as well as weaknesses that often create considerable controversy about their leadership; Ham et al. (2017) show how a CEO's narcissistic personality predicts misreporting behavior; and Chatterjee and Pollock (2017) study how a narcissistic CEO affects governance structures and the acquisition of social approval benefits. Although an important personality trait, narcissism (a belief that an individual is uniquely special and entitled to praise and admiration) only characterizes an individual with respect to one angle. Studies examining only one trait, such as narcissism or hubris, likely omit other important constructs, some of which might be considered important in organizational outcomes (Hough et al. 2015). Furthermore, personality traits (including narcissism) are difficult concepts to measure objectively in large samples. Recent studies have begun to make use of advances in content analysis techniques to understand executives' personality; however, rather than employing broader trait frameworks such as the Big Five, these studies tend to focus on discrete or binary attributes of CEOs and do not directly validate individual traits with existing psychometrics-based instruments. For example, narcissism 
is often estimated based on the prominence of the CEO's photograph in the company's annual report (Gerstner et al. 2013), the CEO's signature size in annual reports (Ham et al. 2017), the CEO's prominence in the company's press releases (Zhu and Chen 2015), the cash and non-cash compensation of the CEO relative to other top executives in the same company (Tang et al. 2018), and employees' subjective ratings of their CEO's personality (O’Reilly et al. 2014).

Our study follows a stream of research that employs the Big Five personality framework, which has emerged as the dominant taxonomy for understanding CEO personality because it provides a more holistic view of individuals' overall personalities. Our measure of risk tolerance is derived from the Big Five traits (orthogonal to one another) that portray basic underlying dimensions of personality (Goldberg 1990) and are recognized as genetically based, relatively stable, and generalizable across cultures (Cobb-Clark and Schurer 2012; Costa and McCrae 1997). For example, Colbert et al. (2014) provide a detailed literature review on how the Big Five personality traits are theoretically associated with firm performance; DeRue et al. (2011) find that leaders' personality traits are often seen as either task oriented (conscientiousness, neuroticism, and openness) or interpersonally oriented (extraversion and agreeableness); and Judge et al. (2002) indicate that openness to experience predicts performance in individual leadership effectiveness, that extraversion is the best personality predictor of leadership, and that high agreeableness does not contribute to success as a leader. This research stream has typically utilized Q\&A sessions of conference calls (specifically, CEOs' answers to analysts' questions) as inputs for linguistic analysis (Harrison et al. 2019; Malhotra et al. 2018; Matsumoto et al. 2011) to determine CEOs' personality traits that have been validated in a large sample setting (Hrazdil et al. 2020).

\subsection{CEO Risk Tolerance and Corporate Governance Structure}

The CEO-board relationship history in corporate governance research, while producing several findings, has left gaps to be explored. For example, Westphal and Zajac (1995, 1996) find that powerful CEOs manage the CEO-board relationship by selecting new directors with similar demographic characteristics or directors who previously served on passive boards. However, little is known about the role CEOs' personalities play in new director selection, the resulting CEO-board power relationship, or whether, and what types of, CEOs select more or less independent board members. Prior literature also provides extensive evidence on the determinants of corporate board size and composition. For example, Boone et al. (2007) test the negotiation hypothesis (Baker and Gompers 2003; Hermalin and Weisbach 1998) that corporate boards reflect the outcome of CEO and outside board members' negotiations, providing evidence that board size and independence increase as firms grow and diversify, board independence is negatively related to manager influence, and board size reflects a tradeoff between firm-specific benefits and monitoring costs. Graham et al. (2020) find that in the year a new CEO is hired, board independence increases, consistent with new $\mathrm{CEO}$ s having less bargaining power, but board independence declines as CEO tenure increases resulting in a higher probability of CEOs becoming board chair and being awarded higher compensation. Finally, prior literature introduces personality theories to corporate governance research on director selection: Zhu and Chen (2015) provide some evidence on why CEOs favor new directors who share their own narcissistic tendency or directors who have prior experience with other similarly narcissistic CEOs. The aforementioned evidence is, however, silent on whether and how the alignment between CEO personality and governance structures affects company performance.

Agency theory prescribes that effective control mechanisms may prevent managers from making suboptimal decisions to maximize their own interests at the expense of shareholders' interests. This theory suggests that companies might mitigate this agency cost by using boards of directors to effectively monitor managers (Byrd and Hickman 1992; Fama and Jensen 1983). Fama and Jensen (1983) argue that boards of directors will be more effective in monitoring managers when the boards are dominated by independent directors. Westphal (1999) argues that inside directors are ineffective in monitoring managers 
because they are often under considerable pressure to conform to managers' wishes. Dallas (2003) asserts that more outside directors are needed to enable the board to challenge, negotiate, and even terminate a manager's contract. We concur with Dallas (2003) and argue that independent directors are more effective in challenging and negotiating with CEOs, particularly with respect to decisions involving excessive risks. We argue that the level of CEO risk tolerance should be aligned with the ratio of independent directors on boards. Hence, we hypothesize that CEO risk tolerance (RT) will be positively associated with board independence.

Hypotheis 1 (H1). CEO risk tolerance is positively related to board independence.

CEO duality creates a concentration of power and might diminish the effectiveness of a company's control mechanisms (Wu 2021). Recent developments in corporate governance structure (e.g., Business Roundtable 2016; OECD 2015) recommend separating the roles of CEO and chairman of the board. Gul and Leung (2004) argue that CEO duality allows the CEO significant influence over the board of directors, which may impede the board's ability to oversee managerial decisions and activities. In this study, we argue that CEO duality causes a concentration of power enabling the CEO to pursue investments with excessive risks without proper monitoring from the board. Hence, a CEO with a high level of risk tolerance is not a good match with CEO duality. We predict that CEO RT will be negatively associated with CEO duality.

Hypotheis 2 (H2). CEO risk tolerance is negatively related to CEO duality.

Board size can determine the effectiveness of the manager-monitoring activities conducted by the board. Yermack (1996) argues that larger boards are less effective in monitoring managers and more prone to CEO influence. Yermack (1996) also suggests that the benefits of a small board size include greater ownership and accountability, ease of scheduling meetings, greater member participation, idea sharing, cohesion, and a sense of common purpose. In this study, we argue that smaller boards will be more effective in challenging and negotiating with the CEOs to mitigate their excessive risk seeking. Hence, we hypothesize that board size will be negatively related to CEO RT.

Hypotheis 3 (H3). CEO risk tolerance is negatively related to board size.

Nationality mix is valuable to a company because it introduces different points of view and strategies (Carter et al. 2010). Increased board diversity may stimulate more heterogeneous opinions and more critical thinking resulting in more innovative and creative solutions (Carter et al. 2010). We argue that nationality mix is a good fit with CEO RT because it promotes critical thinking, and creative solutions when negotiating with CEOs, particularly those with a high level of risk tolerance. Therefore, we expect that nationality mix will be positively related to CEO RT.

Hypotheis $4 \mathbf{~ ( H 4 ) . ~ C E O ~ r i s k ~ t o l e r a n c e ~ i s ~ p o s i t i v e l y ~ r e l a t e d ~ t o ~ n a t i o n a l i t y ~ m i x . ~}$

Researchers have argued that there are differences between the management styles of men and women due to differences in problem solving and perceptual vision (Perryman et al. 2016) as well as risk preferences and attitudes (Charness and Gneezy 2012). In a metaanalysis of 140 studies, Post and Bryon (2015) find a positive relationship between females on boards and both strategy involvement and monitoring. Accordingly, we argue that the presence of female directors will help CEOs to be more careful in pursuing excessively risky projects. A higher female ratio will be a good match with a higher level of CEO RT. Hence, we predict that the gender ratio (ratio of male directors to total directors) will be negatively associated with CEO RT.

Hypotheis 5 (H5). CEO risk tolerance is negatively related to gender ratio. 


\subsection{CEO Risk Tolerance, Corporate Governance, and Firm Performance}

Daily et al. (2003) and Adams et al. (2010) survey both theoretical and empirical studies on corporate governance and firm performance, indicating mixed evidence for the hypothesis that enhancing corporate governance improves financial performance. The equivocal support for this hypothesis has been attributed to board composition variance across firms (Coles et al. 2008) and that determination of governance structures remains largely unknown (Boone et al. 2007). ${ }^{4}$ Possible explanations for these findings include the influence of the Sarbanes-Oxley Act of 2002, multiple factors simultaneously affecting financial performance, the fact that corporate performance over time is unlikely to be affected by board independence, and the lack of frequent board meetings (Hermalin and Weisbach 2003; Linck et al. 2009).

More recent literature offers additional insights into the determinants of board structures and governance and calls for the consideration of potential unintended consequences of 'effective' board composition and leadership strategies (Finkelstein et al. 2009). For example, Del Brio et al. (2013) use social exchange theory to indicate that board members' perceptions of the CEO's ability, benevolence, and integrity have different effects on board members' resource provision and monitoring, whereas Peteghem et al. (2018) show how board diversity can give rise to the formation of subgroups along fault lines, which may reduce board effectiveness. Recognizing board-executive dynamics and that top management is charged with leading the organization, executives' psychological makeup and the composition of the inner circle of executives have been suggested to play a role in influencing organizational effectiveness and firm performance (Abatecola et al. 2013; Colbert et al. 2014). ${ }^{5}$

We contribute to both streams of literature by analyzing the influence of CEO personality traits on corporate governance and firm performance. Accordingly, we rely on upper echelons theory to highlight the influence of CEO personality traits and employ a contingency approach to investigate the performance implications of alignment between $\mathrm{CEO}$ traits and a firm's governance structures. This approach relies on the premise that to be effective, governance structures must be matched to contextual variables such as CEO personality and other firm characteristics (e.g., size, leverage). ${ }^{6}$ Accordingly, we develop our hypotheses on a premise that a good fit (or alignment) between a CEO's personality and governance structure has a positive impact on performance. ${ }^{7}$ Specifically, we argue that the impact of corporate governance (represented in this study by CEO duality, board independence, board size, ratio of males to total number of directors, and nationality mix of the board members) on performance differs across the level of CEO risk tolerance. On the one hand, an increased level of CEO risk tolerance is a good fit with more independent directors on the board and a higher ratio of a board's nationality mix. On the other hand, an increased level of CEO risk tolerance is a misfit with CEO duality, a larger board size, and a lower number of female board members.

Given the evidence that personality can substantially influence an individual's relationships with others (e.g., Colbert et al. 2014), we extend the upper echelons perspective on how $\mathrm{CEO}$ personality traits and different corporate governance structures help explain firm financial performance.

We recognize that CEOs' (or top management teams') personality and background traits influence organizational performance (Hambrick and Mason 1984; Hambrick 2007). Given that existing studies provide separate examinations of CEO traits and governance (e.g., Zhu and Chen 2015; Chatterjee and Pollock 2017) and CEO traits and financial performance aspects (e.g., Hackbarth 2008; Malmendier et al. 2011), we contribute to the literature by examining how the misalignment of CEO personality and corporate governance structures is associated with financial performance.

This discussion leads to our sixth hypothesis, stated in the alternative form:

Hypotheis 6 (H6). Misalignment of CEO risk tolerance and governance structures is negatively related to firm financial performance. 


\section{Research Methods and Sample}

\subsection{Research Model}

To examine the relationship between corporate governance and firm financial performance in a multidimensional way, we utilize the verbal communication of CEOs of large U.S. companies to identify their fundamental Big Five (OCEAN) personality traits. ${ }^{8}$ The Big Five, developed by Norman (1963) and Costa and McCrae (1992), is one of the most widely used personality models to describe how a person generally engages with the world. Specifically, integrating personality and leadership theories with upper echelons theory, we examine whether the misalignment between CEOs' personal characteristics and corporate governance structures affects firm financial performance. As noted, our focus relates to recent evidence that behavioral traits of executives affect corporate financial policies approved by the board (e.g., capital structure, financing, compensation packages, investment management style, and long-term firm survival).

A well-accepted theory of psychology and other social-related fields is that human language reflects personality, thinking style, social connections, and emotional states. The frequency with which we use certain categories of words can provide clues regarding these characteristics. Fast and Funder (2008) and Yarkoni (2010) document that variations in word usage in written essays, blogs, and tweets predict certain aspects of personality. Others utilize executive speeches during conference calls as inputs to machine-learning algorithms to infer and validate their Big Five personality traits. For example, Harrison et al. (2019) apply machine-learning algorithms to train models to estimate OCEAN and document significant effects of CEOs' personality traits on strategic change, where the nature of these effects differs based on recent firm performance. Hrazdil et al. (2020) validate that OCEAN traits obtained from IBM Watson are CEO specific and unrelated to firm characteristics, validate that CEO risk tolerance based on OCEAN varies with existing inherent and behavior-based measures for risk in predictable ways, and document a significant effect of inherent CEO risk tolerance on audit fees. Recent literature utilizes IBM Watson to obtain CEOs' Big Five traits to test their association with corporate social responsibility performance and reporting (Hrazdil et al. 2021; Mahmoudian et al. 2021).

IBM Watson, analyzing verbal communications, infers portraits of individuals that reflect their personality characteristics and returns a personality profile of the input. ${ }^{9}$ We utilize this linguistic analytics software to infer CEOs' intrinsic Big Five personality characteristics from publicly available transcribed conference calls related to fiscal year-end firm performance. Following Hrazdil et al. (2020), we specifically focus on the question and answer (Q\&A) period of conference calls related to year-end earnings announcements, which represent a voluntary disclosure mechanism (Davis et al. 2015). The unstructured and unregulated Q\&A period provides a standardized setting for collecting executives' personality profiles from their verbalized opinions on questions posed by analysts. By focusing only on conference calls related to earnings announcements, we control for the underlying economic news communicated in the disclosure (i.e., earnings surprise).

To capture CEOs' tolerance for risk, Hrazdil et al. (2020) use Big Five scores to compute a risk-tolerance (RT) index, based on previous research that documents a relatively consistent relationship between the five traits and risk tolerance. Specifically, prior research has found that low agreeableness, low neuroticism, high openness, high extraversion, and low conscientiousness (Clarke and Robertson 2005; Costa and McCrae 1997; Hong and Paunonen 2009; Gullone and Moore 2000; Nadkarni and Herrmann 2010; Nicholson et al. 2005; Soane and Chmiel 2005) are associated with high tolerance of risk. To capture this association, Hrazdil et al. (2020) reverse code and compute the RT index based on the personality trait sum, as shown in Equation (1).

$$
\mathrm{RT}=[\mathrm{O}+(100-\mathrm{C})+\mathrm{E}+(100-\mathrm{A})+(100-\mathrm{N})] / 5
$$

Equation (1) follows the approach by Dawes (1979), who demonstrates that linear models (i.e., based on unit or equal weighting) are superior to clinical intuition in predict- 
ing a numerical criterion from numerical predictors. ${ }^{10}$ The risk tolerance index relies on research that finds important relationships between the OCEAN traits and CEOs' comfort with risk (details provided in Hrazdil et al. 2020). This index blends the five traits to acquire an overall CEO portrait, capturing the Big Five personality dimensions' contribution to predicting performance (Hirsh 2010; Judge et al. 2002).

To verify that our proxy for inherent risk tolerance captures CEOs' risk-taking actions, we follow Cain and McKeon (2016) who validate that pilot certification is a proxy for personal risk-taking, and test whether CEOs who are certified pilots are more risk tolerant than non-pilots.

We examine the effect of firm governance structure and CEO RT misalignment on performance using the two-stage approach proposed by Ittner and Larcker (2001). Gerdin and Greve (2004) classify this approach as a Cartesian method. We assume that a crosssectional sample is composed of organizations that vary with respect to the optimal level of governance structure. This assumption is consistent with Milgrom and Roberts' (1992) argument that organizations may be dynamically learning and moving toward the optimal level, but a cross-sectional sample consists of observations distributed around the optimal choice. The observed cross-sectional variation in practices provides a means to assess the performance consequences of CEO RT and a firm's choice of governance structure.

Many different corporate governance structures have been discussed in the literature (e.g., Luo and Salterio 2014). Instead of employing all or most of these structures, we focus on a few recognized "best practices" (Kent et al. 2016; Tingle 2017) or those previously found to affect firm performance (e.g., Ghosh et al. 2015; Cornett et al. 2009; Garcia-Meca and Sánchez-Ballesta 2009; Yermack 1996; Bennedsen et al. 2008; Reguera-Alvarado et al. 2017; Galbreath 2018). The governance structures we use are CEO/chair duality (i.e., board chair and $\mathrm{CEO}$ are the same individual), number of independent directors (i.e., independent directors are thought to provide better control over a CEO's actions), board size, and board diversity (i.e., gender and ethnicity).

We follow Meyer and Zucker (1989) and argue that a cross-sectional sample comprises firms that vary with respect to the most suitable level of CEO RT. In our first stage, the range of possible combinations of governance structure and CEO RT level is depicted in Equation (2).

$$
\begin{aligned}
\mathrm{RT}_{\text {it }}=\alpha_{0} & +\alpha_{1} \text { CEODual }_{\text {it }}+\alpha_{2} \text { BoardSize }_{i t}+\alpha_{3} \text { IND }_{\text {it }}+\alpha_{4} \text { GenRatio }_{i t} \\
& +\alpha_{5} \mathrm{NAT}_{\text {it }}+\Sigma \alpha_{\text {it }} \text { Controls }+ \text { Firm FE }+ \text { Year FE }+\varepsilon
\end{aligned}
$$

where CEODual is a dummy variable equal to 1 if the $\mathrm{CEO}$ is also the board chair and zero otherwise; BoardSize is the number of directors on the board; IND is the ratio of the number of independent directors to the total number of directors on the board; GenRat is the ratio of the number of male directors to the total number of directors on the board; NAT is the nationality mix of board members; Controls are Female (a dummy variable with a value of 1 when the CEO is female and zero otherwise), SIZE (natural logarithm of total assets), $L E V$ (leverage), and $R \mathcal{E} D$ (R\&D intensity equal to $R \& D$ expenditures/Total assets); and FirmFE and YearFE are firm and year fixed effects, respectively. Equation (2) is designed to signal the optimal level of CEO risk tolerance based on corporate structure and financial characteristics, as well as firm and year fixed effects. The rationale is that decisions on CEO succession are determined by boards based on firms' challenges and goals. Although most of the board characteristics in Equation (2) are relatively constant, the financial and regulatory situations vary from year to year, and Equation (2) serves to capture the optimal level of CEO risk tolerance based on both board characteristics and current firm scenarios. However, it is common to expect misalignments from current to "optimal" CEO risk tolerance. First, boards often fail to choose the right CEO for reasons such as lack of information about candidates or biases from the search committee (Khurana 2001). Secondly, the current CEO risk tolerance level is likely to become unsuitable as the company experiences material change in corporate structure or financial environment. Thus, in the 
second step, we use the residuals for each observation to estimate the misalignment of CEO risk tolerance from the estimated 'optimal' level (Ittner and Larcker 2001).

Following Ittner and Larcker (2001), we use Equation (2) (the first stage) to estimate the appropriate benchmark level of CEO RT for the combination of governance structure variables. If the benchmark model represents an optimal CEO RT level, then any deviations from the estimated model (i.e., either too little or too much RT) should be negatively associated with firm performance. Ittner and Larcker (2001) propose that the residuals for each observation, whether positive or negative, estimate the distance by which the firm deviates from the "optimal' level of CEO RT (Equation (1)). Hence, the absolute value of the residuals generated from Equation (2) $(|\varepsilon|)$ indicates the misfit from the optimal governance structure-CEO RT configuration.

In our second stage and following the upper echelons literature, we examine this relationship employing commonly used organizational effectiveness measures of firm financial performance (i.e., return on common equity $(R O E$, the ratio of the firm's net income to shareholders' equity) and Tobin's $Q$ (TOBQ, the ratio of the firm's market value to the replacement cost of its assets, following Lang et al.'s (1989) definition)). We regress these performance measures on the absolute value of the residuals to investigate the impact of the CEO RT-governance structure misfits on performance. Specifically, Equation (3) tests this prediction, where the absolute residuals $\left|\varepsilon_{\text {it }}\right|$ are obtained from Equation (2).

$$
\text { PERFORMANCE MEASURES }_{\mathrm{it}}=\gamma_{0}+\gamma_{1}\left|\varepsilon_{\mathrm{it}}\right|+v
$$

Accurate measurement of variables is essential for drawing valid statistical inferences from empirical samples. Inaccurate measurement or noisy proxies and drawing inferences about the significance of personality characteristics for various outcomes can often result in type I errors (observing a difference when none exists) and type II errors (failing to observe a difference when one does exist). Two ways to minimize type I and type II errors are to increase the sample size or to provide a better technique for measuring variables. In this study, our ability to analyze a large sample of firm observations (8208) and objectively assess CEO RT based on several personality dimensions assists us in minimizing both types of errors.

\subsection{Sample}

Our sample data originate from the following sources: (1) compensation committee structures, board composition, director profiles, CEO directors' current and past appointments, and activities from BoardEx (North American Region); (2) stock return data from the Center for Research in Security Prices (CRSP) daily return files; (3) book-to-market ratio, firm size, and other financial variables from annual Compustat files; and (4) Big Five personality traits from IBM Watson. We manually searched proxy statements to obtain variables related to board independence (i.e., CEO duality, insider/outsider, audit committee independence, and board capital - the capability of board members based on their social status) and to verify the names of CEOs and board chairs. Using these sources, we collected our data for the years 2002 through 2013. The data requirements resulted in a sample of 8208 firm-year observations (1818 unique firms and 1605 CEOs). The distribution of our sample by year is shown in Table 1.

We drew the initial sample of CEOs from the ExecuComp database during 2002-2013, which primarily covers firms in the Standard \& Poor (S\&P)'s 1500 Index. We then obtained pilot information from the Federal Aviation Administration (FAA)'s online airmen inquiry website, which contains names, certificate levels, and rating information for all registered pilots in the United States. ${ }^{11}$ We first searched for CEO names; if a given CEO's name did not produce a match in the FAA's database, then we coded this observation as a non-pilot and no further validation was necessary. In other cases, using the name alone was not sufficient to identify a CEO. If a given name produced at least one name match in the FAA's database, we then confirmed whether the pilot certificate belonged to the sample CEO. We used LexisNexis, Bloomberg, and public records searches to obtain birth dates, home 
addresses, and other personal information on the CEOs that could be used to validate the FAA certificate information. We then used CEOs' dates of birth in addition to their names to identify pilots, as dates of birth do not change over time. The manual data checking resulted in a final sample of 145 pilot-year CEOs and 4422 non-pilot years. The mean (median) RT for this subsample is 52.4 (52.6). Our validation test reveals that the RT of pilot CEOs is 54.0 compared with 52.5 for non-pilot CEOs. This difference is statistically significant with a $p$-value of 0.001 .

Table 1. Sample distribution.

\begin{tabular}{cccc}
\hline Fiscal Year & Frequency & Percent & Cumulative \\
\hline 2002 & 201 & 2.45 & 2.45 \\
2003 & 391 & 4.76 & 7.21 \\
2004 & 430 & 5.24 & 12.45 \\
2005 & 519 & 6.32 & 18.77 \\
2006 & 598 & 7.29 & 26.06 \\
2007 & 702 & 8.55 & 34.61 \\
2008 & 803 & 9.78 & 44.40 \\
2009 & 824 & 10.04 & 54.43 \\
2010 & 864 & 10.53 & 64.96 \\
2011 & 976 & 11.89 & 76.85 \\
2012 & 975 & 11.88 & 88.73 \\
2013 & 925 & 11.27 & 100.00 \\
Total & 8208 & 100.00 & \\
\hline
\end{tabular}

\section{Results}

Table 2 provides summary statistics for the variables included in Equations (1)-(3). RT has a range between 13.4 and 77.0 on a scale of 100 with a median of 52 . On average, approximately one third of CEOs are also board chairs, and 1\% are female. On average, $68 \%$ of directors are independent, ranging from $12 \%$ to $92 \%$. We measured our gender ratio as males on the board/total number of board members. This average gender ratio is $90 \%$ male and ranges between $60 \%$ and $100 \%$, whereas national diversity on the board is low on average $(8 \%)$, ranging between 0 and $60 \%$. The board size of an average company is approximately nine directors, ranging between 4 and 16 . The ROE average is $5 \%$ and the average Tobin's Q is 1.76 .

Pearson's correlations between variables are displayed in Table 3 for RT, board and CEO characteristics, performance, and control variables. First, RT is significantly positively correlated with firm performance and not correlated with Tobin's Q. Second, RT is significantly positively correlated with IND, BoardSize, Size, and NAT, indicating that the more risk tolerant a CEO, the more likely s/he is to manage a larger firm and to be governed by a larger board that contains more independent directors with more diverse nationalities. RT is significantly negatively correlated with GenRat, indicating that the more risk tolerant is a CEO, the less likely s/he is to be governed by a board with a higher percentage of male board members. Finally, the significant negative correlation between RT and $R \& D$ intensity signals that a more risk-tolerant CEO engages in lower R\&D intensity. We interpret these findings as general support for our hypotheses $H_{1}$ through $H_{5}$ that CEO risk tolerance, based on the Big Five personality traits, is associated with the corporate governance structures examined in this study. ${ }^{12}$

Table 4 presents the first-stage regression results based on a sample of 8208 observations. Consistent with our expectations, we find that RT and duality are significantly negatively associated $\left(\mathrm{H}_{2}\right)$ and that $\mathrm{CEOs}$ who manage larger firms and who are governed by boards with more independent $\left(H_{1}\right)$ and more ethnically diverse board members $\left(H_{4}\right)$ are more risk tolerant than their counterparts in smaller organizations overseen by fewer independent or minority directors. The results show that gender diversity $\left(H_{5}\right)$ and board size $\left(H_{3}\right)$ are not significantly related to CEO risk tolerance although the signs are consistent with our expectations. While we expect that R\&D intensity is positively associated with 
CEO RT, the result indicates the opposite. We offer two possible explanations for this result. First, a reexamination of our data shows that the majority of our sampled firms did not report $R \& D$ expenditures (the median is zero). Second, most $R \& D$ expenditures are treated as current-period expenses, which reduce reported income. Hence, an influential CEO might be inclined to reduce the resources spent on R\&D activities in order to maximize short-term reported income. Overall, our results are consistent with our first hypothesis, supporting the premise that a CEO's RT is associated with corporate governance structures.

Table 2. Summary statistics.

\begin{tabular}{|c|c|c|c|c|c|c|c|}
\hline Variable & Mean & Standard Deviation & Minimum & 25th Percentile & Median & 75th Percentile & Maximum \\
\hline RT & 51.87 & 6.28 & 13.40 & 48.20 & 52.00 & 56.00 & 77.00 \\
\hline $\mathrm{ROE}$ & 0.05 & 0.23 & -1.27 & 0.01 & 0.10 & 0.17 & 0.37 \\
\hline TOBQ & 1.76 & 1.56 & 0.10 & 0.91 & 1.30 & 2.07 & 36.54 \\
\hline IND & 0.68 & 0.13 & 0.12 & 0.60 & 0.71 & 0.78 & 0.92 \\
\hline CEODual & 0.33 & 0.47 & 0.00 & 0.00 & 0.00 & 1.00 & 1.00 \\
\hline BoardSize & 8.63 & 2.20 & 4.00 & 7.00 & 8.00 & 10.00 & 16.00 \\
\hline NAT & 0.08 & 0.15 & 0.00 & 0.00 & 0.00 & 0.10 & 0.60 \\
\hline GenRat & 0.90 & 0.10 & 0.60 & 0.85 & 0.90 & 1.00 & 1.00 \\
\hline Female & 0.01 & 0.12 & 0.00 & 0.00 & 0.00 & 0.00 & 1.00 \\
\hline LEV & 0.28 & 0.25 & 0.00 & 0.02 & 0.26 & 0.45 & 0.97 \\
\hline SIZE & 6.88 & 1.79 & 2.55 & 5.64 & 6.79 & 8.08 & 11.57 \\
\hline R\&D & 0.13 & 0.53 & 0.00 & 0.00 & 0.00 & 0.07 & 7.17 \\
\hline
\end{tabular}

RT (risk tolerance, an index combining the five OCEAN traits denoted by O (openness); C (conscientiousness); E (extraversion); A (agreeableness); $\mathrm{N}$ (neuroticism), defined by Equation (1)) is based on conference calls during year $t$; ROE (return on equity, income before extraordinary items/shareholder's equity); TOBQ (Tobin's $Q$, the ratio of the firm's market value to the replacement cost of its assets, following Lang et al. 1989); CEODual (dummy variable with a value of 1 when the CEO is also the chair of the board and 0 otherwise); BoardSize (number of directors on a company's board); IND (number of independent board directors/total number of board members); GenRat (number of male board members/total number of board members); NAT (nationality mix, defined as the number of directors from different countries/total number of directors); Female (dummy variable with a value of 1 when the CEO is female and 0 otherwise); LEV (total debt/total equity); SIZE (natural logarithm of company's total assets); and R\&D (research and development expenditures/total assets at end of period). Missing values of Female and NAT have been set to 0, and all variables are winsorized at $1 \%$ and $99 \%$ levels.

Table 3. Pearson's correlations.

\begin{tabular}{|c|c|c|c|c|c|c|c|c|c|c|c|c|c|}
\hline Variable & & I & II & III & IV & $\mathrm{V}$ & VI & VII & VIII & IX & $X$ & XI & XII \\
\hline RT & I & 1.00 & & & & & & & & & & & \\
\hline ROE & II & 0.06 & 1.00 & & & & & & & & & & \\
\hline TOBQ & III & 0.01 & -0.01 & 1.00 & & & & & & & & & \\
\hline IND & IV & 0.05 & 0.08 & 0.29 & 1.00 & & & & & & & & \\
\hline CEODual & V & 0.01 & 0.19 & -0.05 & 0.22 & 1.00 & & & & & & & \\
\hline BoardSize & VI & 0.05 & 0.14 & -0.09 & 0.22 & 0.25 & 1.00 & & & & & & \\
\hline NAT & VII & 0.09 & -0.02 & -0.01 & -0.05 & 0.16 & -0.05 & 1.00 & & & & & \\
\hline GenRat & VIII & -0.03 & -0.11 & -0.01 & -0.19 & -0.19 & -0.18 & -0.04 & 1.00 & & & & \\
\hline Female & IX & 0.00 & 0.04 & 0.02 & -0.19 & 0.05 & 0.06 & 0.01 & 0.01 & 1.00 & & & \\
\hline LEV & $X$ & 0.00 & 0.01 & 0.09 & -0.10 & 0.28 & 0.06 & 0.03 & 0.01 & 0.00 & 1.00 & & \\
\hline SIZE & XI & 0.14 & 0.32 & 0.35 & -0.31 & 0.63 & 0.20 & 0.06 & 0.16 & 0.44 & 0.43 & 1.00 & \\
\hline R\&D & XII & -0.06 & -0.27 & -0.12 & 0.02 & -0.10 & 0.00 & -0.02 & 0.06 & -0.14 & -0.15 & -0.23 & 1.00 \\
\hline
\end{tabular}

All variables are defined in Table 2. Correlations that are significant at the $5 \%$ level are in in boldface.

The second-stage regression results from Equation (3) are reported in Table 5. The variables ehat (absolute value of the residuals), ehat_neg (negative residuals), and ehat_pos (positive residuals) are the residuals from the regression (Equation (2)) shown in Table 4 and capture the relationship between CEO RT and the governance variables taken together, including the control variables. We use these residuals to explain company financial performance.

Our second hypothesis predicts that misalignment between CEO RT and a firm's governance structures has a negative impact on firm performance. Table 5 presents the results of ordinary least squares (OLS) regressions testing the impact of CEO risk tolerancegovernance structure misfit on firm performance, as measured by ROE and TOBQ. The results indicate that the relationship between misfit (as measured by the absolute residuals 
(ehat, $\left.\left|\varepsilon_{\mathrm{it}}\right|\right)$ and both ROE and TOBQ is negative and significant $(\gamma=-0.00415, p<0.05$ and $\gamma=-0.00655, p<0.05$ for ROE and TOBQ, respectively). These results are consistent with our premise that misalignment between CEO RT and a firm's governance structures has a detrimental effect on performance.

Table 4. Regression results-First stage.

\begin{tabular}{cc}
\hline Dependent Variable & RT \\
\hline IND & $1.549^{* * *}$ \\
CEODual & {$[10.15]$} \\
& $-0.807^{* *}$ \\
BoardSize & {$[-2.45]$} \\
& -0.129 \\
GenRatio & {$[-1.61]$} \\
& -1.382 \\
NAT & {$[-0.88]$} \\
& $2.311^{* *}$ \\
Female & {$[2.40]$} \\
& -0.561 \\
LEV & {$[-1.04]$} \\
SIZE & -0.635 \\
& {$[-1.24]$} \\
R\&D & $0.870^{* * *}$ \\
& {$[10.15]$} \\
Constant & $-0.369^{* *}$ \\
Firm FE & {$[-2.34]$} \\
Year FE & $47.230^{* * *}$ \\
$N$ & {$[25.29]$} \\
Adjusted $R^{2}$ & Yes \\
Yes & 8208 \\
\end{tabular}

All variables are defined in Table 2. T-statistics based on robust standard errors are reported in brackets. ${ }^{* * *}$ and ${ }^{* *}$ denote significance at $p<0.01$, and $p<0.05$, respectively.

Table 5. Regression results-Second stage.

\begin{tabular}{|c|c|c|c|c|c|c|}
\hline & $\begin{array}{c}\text { ROE } \\
\text { | Residuals | }\end{array}$ & $\begin{array}{c}\text { ROE } \\
\text {-Residuals }\end{array}$ & $\begin{array}{c}\text { ROE } \\
+ \text { Residuals }\end{array}$ & $\begin{array}{c}\text { TOBQ } \\
\text { | Residuals | }\end{array}$ & $\begin{array}{c}\text { TOBQ } \\
\text {-Residuals }\end{array}$ & $\begin{array}{c}\text { TOBQ } \\
+ \text { Residuals }\end{array}$ \\
\hline ehat $\left(\times 10^{2}\right)$ & $\begin{array}{c}-0.415^{* *} \\
{[0.035]}\end{array}$ & & & $\begin{array}{c}-0.655^{* *} \\
{[0.047]}\end{array}$ & & \\
\hline ehat_neg $\left(\times 10^{2}\right)$ & & $\begin{array}{c}0.409 \\
{[0.188]}\end{array}$ & & & $\begin{array}{c}0.871 \\
{[0.202]}\end{array}$ & \\
\hline ehat_pos $\left(\times 10^{2}\right)$ & & & $\begin{array}{c}-0.452 * \\
{[0.064]}\end{array}$ & & & $\begin{array}{l}-0.944 \\
{[0.223]}\end{array}$ \\
\hline Firm FE & Yes & Yes & Yes & Yes & Yes & Yes \\
\hline Year FE & Yes & Yes & Yes & Yes & Yes & Yes \\
\hline Clustered by year & Yes & Yes & Yes & Yes & Yes & Yes \\
\hline $\mathrm{N}$ & 8208 & 3864 & 4042 & 8208 & 3864 & 4344 \\
\hline Adjusted R2 & 0.396 & 0.403 & 0.380 & 0.624 & 0.679 & 0.590 \\
\hline
\end{tabular}

Regression results are based on Equation (3). The variables ehat (absolute value of residuals), ehat_neg (negative residuals), and ehat_pos (positive residuals) are the residuals from the regression shown in Table 4 and capture the relationship between CEO risk tolerance and the governance variables grouped together. All remaining variables are defined in Table 2. $p$-values based on robust standard errors are reported in brackets. ${ }^{* *}$ and ${ }^{*}$ denote significance at $p<0.05$ and $p<0.10$, respectively.

We further followed Ittner and Larcker's (2001) suggestion and tested the assumption that the direction of the residuals (positive or negative) has a symmetrical effect on performance. We ran a separate regression for the positive (ehat_pos) and negative (ehat_neg) residuals on performance and found that the positive residuals are negatively and sig- 
nificantly related to performance $(\gamma=-0.00452, p<0.10$ for ROE). As for the negative residuals, although the effects on performance are positive (as expected) for both ROE and TOBQ, the coefficients are not statistically significant. These results indicate that excessive CEO RT (positive residuals) is more damaging than low CEO RT (negative residuals). Overall, our results are consistent with our second hypothesis that for situations where a misfit exists between the RT of a CEO and the corporate governance structures, there is a negative and significant effect on firm performance. ${ }^{13}$

\section{Discussion, Conclusions, and Directions for Future Research}

Overall, the two hypotheses developed in this study have been fully examined. Our findings indicate that CEO risk tolerance is positively related to board independence and board members' nationality mix. We also find that CEO duality is negatively related to CEO risk tolerance. These findings are consistent with the recommendations of recent corporate governance guidelines (e.g., OECD 2015; Business Roundtable 2016) that the majority of the board members should be independent from management, that the board members should represent diverse nationalities, and that the CEO should not be the chairman of the board of directors. With respect to gender diversity, although it is negatively related to CEO risk tolerance, the relationship is not statistically significant. One plausible explanation for this insignificant result is that gender differences may not be necessary controls on the CEO's risk taking. ${ }^{14}$ Male directors may be able to control aggressive risk taking by a CEO even in cases where gender diversity is low or nonexistent, consistent with others' findings (e.g., Sila et al. 2016). Furthermore, we find that board size is negatively related with CEO risk tolerance, but the relationship is not statistically significant. A plausible explanation for this result allows for both smaller and larger boards to exercise control over CEOs with high risk tolerance. A smaller board size may be a good fit where the $\mathrm{CEO}$ has a higher level of risk tolerance. However, when board members are able to reach a consensus, a larger board size may be able to challenge and negotiate with a risk-tolerant $\mathrm{CEO}$.

With respect to the effect of CEO-governance structure misalignment, we find that such misalignment affects performance negatively. Our study provides useful insights into the need to match CEOs' personalities, particularly their levels of risk tolerance with the characteristics of the board members in terms of board independence, CEO duality, and nationality mix. By employing the two-stage regression and using the residual to represent the misalignment between $\mathrm{CEO}$ risk tolerance and the governance structure, our study systematically measures the extent to which a company diverges from the optimum alignment (Ittner and Larcker 2001). The approach used in our study could help future researchers to rigorously measure the degree of misalignment since the concept of misalignment is a central theme in research employing a contingency approach.

Our paper makes several contributions to the literature. Following Hrazdil et al. (2020), we contribute to research utilizing upper echelon theory by employing a risk tolerance index based on the OCEAN personality traits of CEOs to study how misalignment of governance structures affects performance. We further validate that our proxy for RT is associated with risk-taking actions by CEOs (proxied by pilot licenses), which has implications for future researchers. Unlike a binary variable (license or no license), and the fact that only a small fraction of CEOs have pilot licenses, RT derived from Big Five traits based on conference call transcripts is continuous and can be measured for most CEOs. Further, to the best of our knowledge, we are the first to use CEO personality traits to examine the effect of misalignment between governance structures and performance. Our application of the contingency and a two-stage regression approach allows us to go beyond existing literature that has explored the relationship between corporate governance and performance but has not included CEO risk tolerance. Finally, we believe our results provide some interesting findings with respect to board diversity and the independence of board members. Our findings support board member diversity and independent board members as effective governance practices in ensuring that upper echelon executives 
protect shareholder interest. While diversity is recommended in terms of both gender representation and nationalities of directors, our sample indicates that neither women nor minorities comprise a large percentage of board members. However, in terms of controlling a risk-tolerant CEO, male board directors seem to function well in this capacity. These results have important implications for firms' governance practices and appointments of executives; when firms properly align CEO personality with governance structures, they can experience superior financial performance relative to firms where CEO personality is misaligned with the board/governance structures.

In common with empirical research more generally, this study is not without its limitations and these limitations could provide fruitful terrain for future research. Despite a large number of observations, there remains the possibility that another U.S. sample or an international sample could produce different results. In examining the misalignment of corporate governance and CEO risk tolerance, we do not address how shareholder risk tolerance relates to the appointment of CEOs. Additionally, our hypotheses explore the relationship between $\mathrm{CEO}$ risk tolerance and five corporate governance structures (i.e., board independence, CEO duality, board size, nationality mix, gender) and our financial performance measures are ROE and Tobin's Q. Future researchers could examine the CEO risk tolerance-governance structures relationship using different structures (e.g., existence and membership of board committees that oversee risk, management performance, and board appointments) and they could employ different performance measures such as gross or net profit or market share. Other researchers may wish to examine how CEO risk tolerance affects other operational outcomes such as financing or investing activities or the role of shareholder risk tolerance in appointing CEOs. Finally, our hypotheses consider the five primary personality dimensions as a proxy for a single construct of CEO risk tolerance. This approach follows the Big Five personality framework that is well accepted in the psychology and management literature and is consistent with those of prior studies (e.g., Hrazdil et al. 2020; Cain and McKeon 2016; Goldberg 1990). However, it is possible that variations in the five personality dimensions are not uniform across all the five attributes but are mainly driven by the variations in fewer numbers of dimensions. Future research interested in investigating the effect of an individual trait of the five primary personality dimensions (openness, conscientiousness, extraversion, agreeableness, and neuroticism) might consider each trait as an independent construct.

Author Contributions: Conceptualization, J.J.; methodology, J.J.; software, X.L.; validation, X.L.; formal analysis, X.L.; investigation, J.J.; resources, I.M.G.; data curation, X.L.; writing-original draft preparation, I.M.G.; writing-K.H.; visualization, K.H.; supervision, K.H.; project administration, K.H.; funding acquisition, K.H. All authors have read and agreed to the published version of the manuscript.

Funding: This research was funded by the Social Sciences and Humanities Research Council of Canada, grant number 31-R640084, and by the CPA Canada-CAAA Research Grant Fund, grant number CPA-2-2017-002.

Institutional Review Board Statement: Not applicable.

Informed Consent Statement: Not applicable.

Data Availability Statement: The data are available from the corresponding author upon request.

Acknowledgments: We thank Carolyn Egri, Rafael Rogo, Ray Zhang, and participants at the Hawaii Accounting Research Conference (HARC) for their helpful comments and suggestions. Any errors are ours.

Conflicts of Interest: The authors declare no conflict of interest. 


\section{Notes}

1 We define a misalignment as the degree to which aspects of governance policy (i.e., governance structures) deviate from empirically derived optimal policies and a CEO's risk tolerance. Risk tolerance is the degree of risk that a CEO can withstand in making decisions or taking actions. If governance structures are put in place by a company's board to curtail (or promote) CEO risk-taking, then a CEO with a higher (lower) tolerance for risk may be able to ignore or manipulate those governance structures, resulting in an effect on firm performance.

2 Governance structures refer to the sets of mechanisms and processes that companies use to make sure that managers engage in value-maximizing activities for shareholders and other key stakeholders such as employees, government, and society at large (Merchant and Van der Stede 2017). In this study, governance structures are represented by CEO duality, board independence, board size, ratio of males to total number of directors, and nationality mix of the board members.

3 Companies' effort to search for better alignment is considered good governance in the contingency literature. The effort to search for better alignment, however, is different from the concept of good corporate governance.

4 Despite the studies that suggest boards are ineffective, the literature also contains a prominent set of studies concluding that independent boards influence management behavior and affect corporate performance in significant ways. For example, Pearce and Zahra (1991) and Stearns and Mizruchi (1993) suggest that proactive boards are associated with strong financial performance.

$5 \quad$ Abatecola et al. (2013) and Colbert et al. (2014) provide detailed literature reviews on this topic.

6 For example, on the one hand, the governance literature suggests that to retain more control over his/her actions, a CEO would more likely achieve his/her objectives when they are a chairman of the board, the board size is smaller, the board has fewer independent directors, is less diverse, and has less ethnic representation (Ghosh et al. 2015; Cornett et al. 2009; Garcia-Meca and Sánchez-Ballesta 2009). On the other hand, boards have been shown to be more effective in objectively and effectively overseeing CEOs when the CEO is not chairman of the board and when the board is larger, has more independent members, and exhibits greater diversity in terms of gender and ethnicity (Bennedsen et al. 2008; Galbreath 2018; Reguera-Alvarado et al. 2017; Yermack 1996). As a result, corporate boards reflect the outcome of CEOs' and outside board members' negotiations (Baker and Gompers 2003; Hermalin and Weisbach 1998).

7 While the upper echelons framework supports such assertions, we acknowledge that several other frameworks, spanning population ecology, resource dependence, and contingency theories, all point to the alignment of CEO and organizational attributes with external strategic forces as principal drivers of organizational performance. However, such analyses are beyond the scope of this paper. Given these competing perspectives, our test of the misalignment of CEO risk tolerance and corporate governance structures on firm performance is ultimately an empirical issue.

8 The Big Five personality traits are also known as the five-factor model (FFM). See Toegel and Barsoux (2012) for a complete description of leaders' Big Five personality dimensions.

9 IBM conducted a validation study to understand the accuracy of the service's approach to inferring personality profiles. IBM collected survey responses and Twitter feeds from 1500 to 2000 participants for all characteristics and languages. The machinelearning software continually evolves and improves over time and is available at low cost to the public. The results place the service at the cutting edge of personality inference from textual data, as indicated by Schwartz et al. (2013).

10 Dawes (1979) became one of psychology's most cited papers (Fischhoff 2012).

11 Available at https://amsrvs.registry.faa.gov/airmeninquiry/.

12 We also calculate variance inflation factors (VIFs) for all variables in our regression models to investigate whether multicollinearity is present in our data. Untabulated results show that all VIFs take values less than 6, which does not indicate the presence of harmful collinearity (Dielman 2001).

13 Hrazdil et al. (2020) test whether the CEO RT is stationary using a unit root test and find strong evidence against the null hypothesis of a unit root, concluding that the measure of CEO RT is stationary. As a sensitivity analysis, we follow Hrazdil et al. (2020) and measure each Big Five personality trait for the fiscal year $t$ as the median score over all yearly earnings conference calls up to (and including) the last call for the fiscal year $t$, based on which we calculate risk tolerance. Our results remain robust to this alternative definition of risk tolerance.

$14 \quad$ Hrazdil et al. (2020) document that female executives are less risk tolerant than male executives; however, this result is primarily driven by a significantly larger proportion of female CFOs relative to female CEOs. In our study, female CEOs represent less than $1 \%$ of the whole sample, where no significant differences are observed, consistent with Hrazdil et al. (2020).

\section{References}

Abatecola, Gianpaolo, Gabriele Mandarelli, and Sara Poggesi. 2013. The personality factor: How top management teams make decisions. A literature review. Journal of Management and Governance 17: 1073-100. [CrossRef]

Adams, Renée B., Benjamin E. Hermalin, and Michael S. Weisbach. 2010. The role of boards of directors in corporate governance: A conceptual framework and survey. Journal of Economic Literature 48: 58-107. [CrossRef]

Adrian, Christofer, and Sue Wright. 2020. Perceptions of shareholders and directors on corporate governance: What we learn about director primacy. Accounting and Finance 60: 1209-36. [CrossRef] 
Baker, Malcolm, and Paul A. Gompers. 2003. The determinants of board structure at the initial public offering. Journal of Law and Economics 46: 569-98. [CrossRef]

Bennedsen, Morten, Hans C. Kongsted, and Kasper M. Nielsen. 2008. The causal effect of board size in the performance of small and medium-sized firms. Journal of Banking \& Finance 32: 1098-109. [CrossRef]

Boone, Audra L., Laura C. Field, Jonathan M. Karpoff, and Charu G. Raheja. 2007. The determinants of corporate board size and composition: An empirical analysis. Journal of Financial Economics 85: 66-101. [CrossRef]

Bruns, William J., and John H. Waterhouse. 1975. Budgetary control and organization structure. Journal of Accounting Research 13: 177-203. [CrossRef]

Business Roundtable. 2016. Principles of Corporate Governance; New York. Available online: https:/ / www.businessroundtable.org/ policy-perspectives/corporate-governance/principles-of-corporate-governance (accessed on 15 November 2020).

Byrd, John W., and Kent A. Hickman. 1992. Do outside directors monitor managers? Journal of Financial Economics 32: 195-221. [CrossRef]

Cain, Matthew D., and Stephen B. McKeon. 2016. CEO personal risk-taking and corporate policies. Journal of Financial and Quantitative Analysis 51: 139-64. [CrossRef]

Carter, David A., Frank D'Souza, Betty J. Simkins, and Gary W. Simpson. 2010. The gender and ethnic diversity of US boards and board committees and firm financial performance. Corporate Governance: An International Review 18: 396-414. [CrossRef]

Charness, Gary, and Uri Gneezy. 2012. Strong evidence for gender differences in risk taking. Journal of Economic Behavior E Organization 83: 50-58. [CrossRef]

Chatterjee, Arijit, and Timothy G. Pollock. 2017. Master of puppets: How narcissistic CEOs construct their professional worlds. Academy of Management Review 42: 703-25. [CrossRef]

Ciavarella, Mark A., Ann K. Buchholtz, Christine M. Riordan, Robert D. Gatewood, and Garnett S. Stokes. 2004. The big five and venture survival: Is there a linkage? Journal of Business Venturing 19: 465-83. [CrossRef]

Clarke, Sharon, and Ivan T. Robertson. 2005. A meta-analytic review of the Big Five personality factors and accident involvement in occupational and non-occupational setting. Journal of Occupational and Organizational Psychology 78: 355-76. [CrossRef]

Cobb-Clark, Deborah A., and Stefanie Schurer. 2012. The stability of big-five personality traits. Economics Letters 115: 11-15. [CrossRef]

Colbert, Amy E., Murray R. Barrick, and Bret H. Bradley. 2014. Personality and leadership composition in top management teams: Implications for organizational effectiveness. Personnel Psychology 67: 351-87. [CrossRef]

Coles, Jeffrey L., Naveen D. Daniel, and Lithia Naveen. 2008. Boards: Does one size fit all? Journal of Financial Economics 87: 329-56. [CrossRef]

Cornett, Marcia M., Jamie McNutt, and Hassan Tehranian. 2009. Corporate governance and earnings management at large U.S. banks. Journal of Corporate Finance 15: 412-30. [CrossRef]

Costa, Paul, and Robert R. McCrae. 1992. Revised NEO Personality Inventory (NEO-PI-R) and NEO Five-Factor Inventory (NEO-FFI) Manual. Odessa: Psychological Assessment Resources.

Costa, Paul, and Robert R. McCrae. 1997. Personality trait structure as a human universal. American Psychologist 52: 509-16. [CrossRef]

Daily, Catherine M., Dan R. Dalton, and Albert A. Cannella. 2003. Corporate governance: Decades of dialogues and data. Academy of Management Review 28: 371-98. [CrossRef]

Dallas, Lynne. 2003. The multiple roles of corporate boards of directors. San Diego Law Review 40: 781-820. Available online: http:/ /id.loc.gov/authorities/names/n79122466 (accessed on 21 December 2020).

Davis, Angela K., Weili Ge, Dawn Matsumoto, and Jenny L. Zhang. 2015. The effect of manager-specific optimism on the tone of earnings conference calls. Review of Accounting Studies 20: 639-73. [CrossRef]

Dawes, Robyn M. 1979. The robust beauty of improper linear models in decision making. American Psychologist 34: 571-82. [CrossRef]

Del Brio, Esther B, Toru Yoshikawa, Catherine E. Connely, and Wee L. Tan. 2013. The effect of CEO trustworthiness on directors' monitoring and resource provision. Journal of Business Ethics 118: 155-69. [CrossRef]

DeRue, Scott D., Ned Wellman, Jennifer D. Nahrgang, and Stephen E. Humphrey. 2011. Trait and behavioral theories of leadership: An integration and meta-analytic test of their relative validity. Personnel Psychology 64: 7-52. [CrossRef]

Dielman, Terry E. 2001. Applied Regression Analysis for Business and Economics, 3rd ed. Pacific Grove: Thomson Learning.

Epstein, Larry G. 1998. Risk aversion and asset prices. Journal of Monetary Economics 22: 179-92. [CrossRef]

Fama, Eugene F., and Michael C. Jensen. 1983. Separation of ownership and control. Journal of Law and Economics 26: 301-25. [CrossRef]

Fast, Lisa A., and David C. Funder. 2008. Personality as manifest in word use: Correlations with self-report, acquaintance report, and behavior. Journal of Personality and Social Psychology 94: 334-46. [CrossRef] [PubMed]

Finkelstein, Sydney, Donald C. Hambrick, and Bert Cannella. 2009. Strategic Leadership: Theory and Research on Executives, Top Management Teams, and Boards. New York: Oxford University Press.

Fischhoff, Baruch. 2012. Robyn Mason Dawes (1936-2010). American Psychologist 67: 319-20. [CrossRef]

Galbreath, Jeremy. 2018. Is board gender diversity linked to financial performance? The mediating mechanism of CSR. Business $\mathcal{E}$ Society 57: 863-89. [CrossRef]

Gani, Lindawati, and Johnny Jermias. 2006. Investigating the effect of board independence on performance across different strategies. The International Journal of Accounting 41: 295-314. [CrossRef]

Gani, Lindawati, and Johnny Jermias. 2012. The effects of strategy-management control system misfits on firm performance. Accounting Perspectives 11: 165-96. [CrossRef] 
Garcia-Meca, Emma, and Juan P. Sánchez-Ballesta. 2009. Corporate governance and earnings management: A meta-analysis. Corporate Governance: An International Review 17: 594-610. [CrossRef]

Gerdin, Jonas, and Jan Greve. 2004. Forms of contingency fit in management accounting research-A critical review. Accounting, Organizations and Society 29: 303-26. [CrossRef]

Gerstner, Wolf-Christian, Andreas König, Albrecht Enders, and Donald C. Hambrick. 2013. CEO narcissism, audience engagement, and organizational adoption of technological discontinuities. Administrative Science Quarterly 58: 257-91. [CrossRef]

Ghosh, Aloke, Christo Karuna, and Feng Tian. 2015. Causes and consequences of the CEO also being the chair of the board. Journal of Management Accounting Research 27: 197-223. [CrossRef]

Goldberg, Lewis R. 1990. An alternative description of personality: The big five factor structure. Journal of Personality and Social Psychology 59: 1216-29. [CrossRef]

Graham, John R., Campbell R. Harvey, and Manju Puri. 2013. Managerial attitudes and corporate actions. Journal of Financial Economic 109: 103-21. [CrossRef]

Graham, John R., Hyunseob Kim, and Mark Leary. 2020. CEO-board dynamics. Journal of Financial Economics 137: 612-36. [CrossRef]

Gul, Ferdinand A., and Sidney Leung. 2004. Board leadership, outside directors' expertise and voluntary corporate disclosures. Journal of Accounting and Public Policy 23: 351-79. [CrossRef]

Gullone, Eleonora, and Susan Moore. 2000. Adolescent risk-taking and five factor model of personality. Journal of Adolescence 23: 393-407. [CrossRef]

Hackbarth, Dirk. 2008. Managerial traits and capital structure decisions. Journal of Financial and Quantitative Analysis 43: 843-82. [CrossRef]

Ham, Charles, Mark Lang, Nicholas Seybert, and Sean Wang. 2017. CFO narcissism and financial reporting quality. Journal of Accounting Research 55: 1089-135. [CrossRef]

Hambrick, Donald C. 2007. Upper echelons theory: An update. Academy of Management Review 32: 334-43. [CrossRef]

Hambrick, Donald C., and Phyllis A. Mason. 1984. Upper echelons: The organization as a reflection of its top managers. Academy of Management Review 9: 193-206. [CrossRef]

Harrison, Joseph S., Gary R. Thurgood, Steven Boivie, and Michael D. Pfarrer. 2019. Measuring CEO personality: developing, validating, and testing a linguistic tool. Strategic Management Journal 40: 1316-30. [CrossRef]

Hermalin, Benjamin E., and Michael S. Weisbach. 1998. Endogenously chosen boards of directors and their monitoring of the CEO. American Economic Review 88: 96-118.

Hermalin, Benjamin E., and Michael S. Weisbach. 2003. Boards of directors as an endogenously determined institution: A survey of the economic literature. Economic Policy Review 1: 7-26.

Hirsh, Jacob B. 2010. Personality and environmental concern. Journal of Environmental Psychology 30: 245-48. [CrossRef]

Hong, Ryan Y., and Sampo V. Paunonen. 2009. Personality traits and health-risk behaviours in university students. European Journal of Personality 23: 675-96. [CrossRef]

Hough, Laetta M., Frederick L. Oswald, and Jisoo Ock. 2015. Beyond the Big Five: New directions for personality research and practice in organizations. Annual Review of Organizational Psychology and Organizational Behavior 2: 183-209. [CrossRef]

Hrazdil, Karel, Fereshteh Mahmoudian, and Jamal Nazari. 2021. Executive personality and sustainability: Do extraverted CEOs improve corporate social responsibility? Corporate Social Responsibility and Environmental Management. [CrossRef]

Hrazdil, Karel, Jiri Novak, Rafael Rogo, Christine Wiedman, and Ray Zhang. 2020. Measuring executive personality using machinelearning algorithms: A new approach and audit fee-based validation tests. Journal of Business Finance E Accounting 47: 519-44. [CrossRef]

Hutchinson, Marion, and Ferdinand A. Gul. 2004. Investment opportunity set, corporate governance practices and firm performance. Journal of Corporate Finance 10: 595-614. [CrossRef]

Ittner, Christopher D., and David F. Larcker. 2001. Assessing empirical research in managerial accounting: A value-based management perspective. Journal of Accounting E Economics 32: 349-410. [CrossRef]

Jensen, Michael C., and Kevin J. Murphy. 1990. Performance pay and top-management incentives. Journal of Political Economy 98: 225-64. [CrossRef]

Judge, Timothy A., Joyce E. Bono, Remus Illies, and Megan W. Gerhardt. 2002. Personality and leadership: A qualitative and quantitative review. Journal of Applied Psychology 87: 765-80. [CrossRef] [PubMed]

Kent, Pamela, Richard A. Kent, James Routledge, and Jenny Stewart. 2016. Choice of governance structure and earnings quality. Accounting Research Journal 29: 372-390. [CrossRef]

Khurana, Rakesh. 2001. Finding the right CEO: Why boards often make poor choices. MIT Sloan Management Review 43: 91-96.

King, Robyn, Peter M. Clarkson, and Sandra Wallace. 2010. Budgeting practices and performance in small healthcare business. Management Accounting Research 21: 40-55. [CrossRef]

Lang, Larry H., Rene Stulz, and Ralph A. Walkling. 1989. Managerial performance, Tobin's Q, and the gains from successful tender offers. Journal of Financial Economics 24: 137-54. [CrossRef]

Linck, James S., Jeffry M. Netter, and Tina Yang. 2009. The effects and unintended consequences of the Sarbanes-Oxley Act on the supply and demand for directors. Review of Financial Studies 22: 3287-28. [CrossRef]

Luo, Yan, and Steven E. Salterio. 2014. Governance quality in a "comply or explain" governance disclosure regime. Corporate Governance: An International Review 22: 460-81. [CrossRef] 
Mahmoudian, Fereshteh, Jamal Nazari, Irene Gordon, and Karel Hrazdil. 2021. CEO personality and language use in CSR reporting. Business Ethics, the Environment $\mathcal{E}$ Responsibility 30: 338-59. [CrossRef]

Malhotra, Shavin, Taco F. Reus, Pengcheng Zhu, and Erik M. Roelofsen. 2018. The acquisitive nature of extraverted CEOs. Administrative Science Quarterly 63: 370-408. [CrossRef]

Malmendier, Ulrike, Geoffrey Tate, and Jon Yan. 2011. Overconfidence and early-life experiences: The effect of managerial traits on corporate financial policies. Journal of Finance 66: 1687-733. [CrossRef]

Matsumoto, Dawn, Maarten Pronk, and Erik Roelofsen. 2011. What makes conference calls useful? The information content of managers' presentations and analysts' discussion sessions. The Accounting Review 86: 1383-414. [CrossRef]

Mayfield, Cliff, Grady Perdue, and Kevin Wooten. 2008. Investment management and personality type. Financial Services Review 17: 219-36.

Merchant, Kenneth, and Wim Van der Stede. 2017. Management Control Systems: Performance Measurement, Evaluation and Incentives, 4th ed. London, UK: Pearson.

Meyer, Marshall W., and Lynne G. Zucker. 1989. Permanently Failing Organizations. Newbury Park: Sage.

Milgrom, Paul, and John Roberts. 1992. Economics, Organization and Management. New Jersey: Prentice Hall.

Nadkarni, Sucheta, and Pol Herrmann. 2010. CEO personality, strategic flexibility, and firm performance: The case of the Indian business process outsourcing industry. Academy of Management Journal 53: 1050-73. Available online: https://www.jstor.org/ stable/20788808 (accessed on 1 February 2021).

Nicholson, Nigel, Emma Soane, Mark Fenton-O'Creevy, and Paul Willman. 2005. Personality and domain-specific risk taking. Journal of Risk Research 8: 157-76. [CrossRef]

Norman, Warren T. 1963. Toward an adequate taxonomy of personality attributes: Replicated factor structure in peer nomination personality rating. Journal of Abnormal and Social Psychology 66: 574-83. [CrossRef] [PubMed]

O'Reilly, Charles A., Bernadette Doerr, David F. Caldwell, and Jennifer A. Chatman. 2014. Narcissistic CEOs and executive compensation. Leadership Quarterly 25: 218-31. [CrossRef]

OECD. 2015. OECD Principles of Corporate Governance. Paris: OECDs.

Page, Beau T. 2018. CEO attributes, compensation, and firm value: Evidence from a structural estimation. Journal of Financial Economics 128: 378-401. [CrossRef]

Pearce, John A., and Shaker A. Zahra. 1991. The relative power of CEOs and board of directors: Associations with corporate performance. Strategic Management Journal 12: 135-53. [CrossRef]

Perryman, Alexa A., Guy D. Fernando, and Arindam Tripathy. 2016. Do gender differences persist? An examination of gender diversity on firm performance, risk, and executive compensation. Journal of Business Research 69: 579-86. [CrossRef]

Peteghem, Mathijs V., Liesbeth Bruynseels, and Ann Gaeremynck. 2018. Beyond diversity: A tale of faultlines and frictions in the board of directors. The Accounting Review 93: 339-67. [CrossRef]

Plöckinger, Martin, Ewald Aschauer, Martin R. Hiebl, and Roman Rohatschek. 2016. The influence of individual executives on corporate financial reporting: A review and outlook from the perspective of upper echelons theory. Journal of Accounting Literature 37: 55-75. [CrossRef]

Post, Corine, and Kris Bryon. 2015. Women on boards and firm financial performance: A meta-analysis. Academy of Management Journal 58: 1546-71. [CrossRef]

Reguera-Alvarado, Nuria, Pilar de Fuentes, and Joaquina Laffarga. 2017. Does board gender diversity influence financial performance? Evidence from Spain. Journal of Business Ethics 141: 337-50. [CrossRef]

Schein, Edgar. 1983. The role of the founder in creating organizational culture. Organizational Dynamics 12: 13-28. [CrossRef]

Schwartz, Andrew H., Johannes C. Eichstaedt, Margaret L. Kern, Lukasz Dziurzynski, Stephanie M. Ramones, Megha Agrawal, Michal Kosinski, David Stillwell, Martin E. Seligman, and Lyle H. Ungar. 2013. Personality, gender, and age in the language of social media: The open-vocabulary approach. PLOS ONE 8. [CrossRef]

Seijts, Gerard, Alyson Byrne, Mary M. Crossan, and Jeffrey Gandz. 2019. Leader character in board governance. Journal of Management and Governance 23: 227-58. [CrossRef]

Sila, Vathunyoo, Angelica Gonzalez, and Jens Habendorff. 2016. Women on board: Does boardroom gender diversity affect firm risk? Journal of Corporate Finance 36: 26-53. [CrossRef]

Simerly, Roy L., and Mingfang Li. 2000. Environmental dynamism, financial leverage and performance: A theoretical integration and an empirical test. Strategic Management Journal 21: 31-49. [CrossRef]

Soane, Emma, and Nik Chmiel. 2005. Are risk preferences consistent? The influence of decision, domain, and personality. Personality and Individual Differences 38: 1781-91. [CrossRef]

Stearns, Linda B., and Mark S. Mizruchi. 1993. Board composition and corporate financing: The impact of financial institution representation on borrowing. Academy of Management Journal 36: 603-18. [CrossRef]

Tang, Yi, Daniel Z. Mack, and Guoli Chen. 2018. The differential effects of CEO narcissism and hubris on corporate social responsibility. Strategic Management Journal 39: 1370-87. [CrossRef]

Tingle, Bryce C. 2017. What do we really know about corporate governance? A review of the empirical research since 2000. Canadian Business Law Journal 59: 293-331.

Toegel, Ginka, and Jean-Louis Barsoux. 2012. How to become a better leader. MIT Sloan Management Review 53: 51-60. Available online: https: / / sloanreview.mit.edu/article/how-to-become-a-better-leader/ (accessed on 1 June 2020). 
Waterhouse, John H., and Peter Tiessen. 1978. A contingency framework for management accounting systems research. Accounting Organizations and Society 3: 65-76. [CrossRef]

Westphal, James. 1999. Collaboration in the boardroom: Behavioral and performance consequences of CEO-board social ties. Academy of Management Journal 42: 7-24. [CrossRef]

Westphal, James D., and Edward J. Zajac. 1995. Who shall govern? CEO/board power, demographic similarity, and new director selection. Administrative Science Quarterly 40: 60-83. [CrossRef]

Westphal, James D., and Edward J. Zajac. 1996. Director reputation, CEO-board power, and the dynamics of board interlocks. Administrative Science Quarterly 41: 507-29.

$\mathrm{Wu}, \mathrm{Chiu}-\mathrm{Hui}$. 2021. On the moderating effects of country governance on the relationship between corporate governance and firm performance. Journal of Risk and Financial Management 14: 140. [CrossRef]

Yarkoni, Tal. 2010. Personality in 100,000 words: A large-scale analysis of personality and word usage among bloggers. Journal of Research in Personality 44: 363-73. [CrossRef] [PubMed]

Yermack, David. 1996. Higher market valuation of companies with a small board of directors. Journal of Financial Economics 40: 185-211. [CrossRef]

Zhu, David H., and Guoli Chen. 2015. Narcissism, director selection, and risk-taking spending. Strategic Management Journal 36: $2075-98$. [CrossRef] 